\title{
Review
}

\section{Racial imperatives: Discipline, performativity, and struggles against subjection}

\author{
Nadine Ehlers \\ Indiana University Press, Bloomington, IN, 2012, x+184pp., £17.99/\$25.00, \\ ISBN: 978-0253223364
}

Contemporary Political Theory (2014) 13, e1-e3. doi:10.1057/cpt.2013.30

The theory of gender performativity - the idea that gender identities are constituted through stylized repetitions of bodily acts and that the doing of gender is conditioned by heterosexual gender norms - has had a dramatic effect on the ways in which gender is understood. With this theory, Judith Butler has not only challenged conventional understandings of gender, but also shifted the very terms through which this mode of social difference is conceptualized and discussed. Yet, for the most part, the explanatory range of Butler's theory of performativity has been limited to gender. In Racial Imperatives, Nadine Ehlers seeks to fill this gap in the literature by considering what the theory of performativity tells us about what race is and how it is that individuals are formed as racial subjects. In keeping with Butler's account of gender, Ehlers contends that Blackness and Whiteness - as they have been constructed within the context of the United States - are normative and regulatory ideals through which subjects are formed as raced. According to the theory of race performativity that Ehlers develops, subjects are regularly categorized through a certain racial schema and then must reiterate the norms associated with their particular racial designations through bodily acts such as manners of speech, modes of dress and bodily gestures.

One of Ehlers' central claims in this thoughtful and provocative work is that race is an ongoing, disciplinary practice and that the law is a key instrument in this particular technology of power. According to her, racial categories and the meanings associated with them are produced through discursive power and the law. Within the racial economy of North America, certain legal, pseudo-scientific and popular discourses have generated the dominant understandings of Blackness and Whiteness, the ideas that being Black means having a particular type of skin color, blood and inner essence, and that being White involves having the opposite set of essential attributes. As Ehlers points out, part of what has given these naturalized, binary racial categories their continued force and authority is that they have been consistently reiterated in discourse and have been grounded as material practices within specific institutional 
sites of power. In schools, courtrooms and work places, racial bodies have been compared, differentiated, classified and hierarchized according to these racial standards. Ehlers argues that the law plays a crucial role in the processes by which individuals are compelled to assume normalized racial positions. Laws regarding race define the meanings of racial categories and thereby 'condition the disciplinary creation of race and racial identities' (p. 36).

To flesh out this claim and show how law is used as a modality of racial discipline, Ehlers turns to the 1925 'racial fraud' case of Rhinelander v. Rhinelander. In this case, Alice Rhinelander, a light-skinned woman with an ambiguous racial identity, was accused of passing as White and willfully misleading her former husband, Leonard Rhinelander, into entering an interracial marriage. According to Leonard, Alice misrepresented her racial origins by refusing to perform her 'Black racial identity'. Ehlers argues that the fact that this case came before the court indicated that Alice's ambiguous racial identity could not be tolerated by the law. Alice's body threatened the binary logic of the racial classification system established by the law, and for that reason, had to be made to fit within the dominant schema of racial categorization. As such, the court found in favor of Alice, asserting that the 'Blackness' of her body was visually apparent and that there was no way she could have passed as White. As Ehlers contends, the court not only configured Alice's body as 'Black' but also delimited her racial performative possibilities. The court said who she was and who she could be. For Ehlers, this case represents an example of the productive capacity of the law. When it comes to race, the law not only produces and reinforces the dominant meanings of racial categories but is also used as a vehicle for constituting bodies and identities in accordance with dominant racial norms.

Part of what makes Ehlers' discussion of the law and its role in racial discipline compelling is the way in which it complicates overly simplistic views of power that hold that the law and disciplinary power are antithetical to one another. What Ehlers' discussion reveals are the ways in which law works to supplement and extend discipline. In the case of race, law not only sanctions the racial 'truths' that are necessary for the disciplinary production of racial subjects but also serves as an instrument for reprimanding, punishing and correcting subjects who refuse to assume normalized racial identities. The most important contribution of Ehlers' work, however, is the way in which it expands the explanatory range of Butler's theory of performativity. Through a nuanced and careful analysis of Rhinelander $v$. Rhinelander, Ehlers provides a concrete demonstration of just how useful the notion of performativity could be for explaining what race is and how it operates in everyday life.

Despite this, Ehlers' work leaves many important questions unanswered. First, and perhaps most importantly, it is unclear whether Ehlers' work advances Catherine Rottenberg's earlier account of race performativity. Part of the reason for this is that Ehlers limits her discussion of Rottenberg's theory to a single footnote, where she takes issue with one of Rottenberg's central claims about the differences between 
racial performativity and gendered performativity, namely that identification and the desire-to-be is bifurcated in the case of race. That is, Rottenberg claims that race norms compel Black racial subjects to identify as Black but to desire to be White, but for Ehlers, this claim ignores the complex operations of racial performativity. While there is some basis to this objection, it is not clear whether Ehlers' reading of Rottenberg's position is a fair one. Even more importantly, however, this discussion points to a larger problem with Ehlers' position. By focusing so heavily on the similarities between gender performativity and race performativity, it seems as though Ehlers has, at times, simply transposed gender performativity onto race, replacing the male-female binary with the White-Black binary. As such, there are serious questions as to whether Ehlers's theoretical framework can adequately account for the specificity of race, especially in contexts outside of the United States where the White-Black binary has played a lesser role in the formation of racial difference.

While both Rottenberg and Ehlers provide the groundwork for a theory of race performativity, there is still a lot of work to be done, not only to develop this theoretical account further, but also to show what such a theory could contribute to race theory more generally. How does the theory of race performativity stand in relation to some of the other leading theories of race, especially those that conceptualize race as an ongoing process? Is race performativity just one other framework for describing the ongoing formation of race and racialized subjects? Or does it actually make a significant contribution to some of the leading theories of race? Is there a way in which it furthers a theory like Omi and Winant's theory of racial formation? These are big questions, but they are the sorts of questions that are going to have to be answered in order to show that the notion of race performativity is as useful and as explanatorily powerful as some believe it to be.

Jason Pfeifle

Georgia Fair Share, Decatur, GA 30030, USA jason@fairshareonline.org 